\title{
Effect of water and alkali on purification bacterial cellulose membrane from
}

\section{Kombucha}

\author{
Efeito da água e do álcali na purificação da membrana de celulose bacteriana de Kombuchá \\ Efecto del agua y el álcali en la purificación de la membrana de celulosa bacteriana de Kombucha
}

\begin{abstract}
Bacterial cellulose membrane (BCM) is a biomaterial synthesized by bacteria of the genus Gluconocetobacter hansenii with a higher degree of purity than plant cellulose. The commonly used raw material for manipulating bacterial cellulose is kombucha, a beverage consumed by a vast population around the world that promises health benefits. The beverage is composed of tea species Camellia sinenses and a carbon source, refined sucrose, and a starter culture of bacteria and yeast with $10 \%$ fermented tea (starter tea) to activate the fermentative process. The Kombucha's bacterial cellulose membranes (KBCM) are formed over 7 to 10 days on the surface of the fermented product and have the appearance of a gelatinous membrane, this being the by-product of interest. In this work, the objective was to obtain the membrane composed of cellulose via Kombucha and purify it to obtain crystalline cellulose. The purification was performed with distilled water and $0.5 \mathrm{M} \mathrm{NaOH}$ sodium hydroxide solution to remove residues from the fermentation, successfully removing sugars and bacteria. At the end of the experiments, a lighter film was obtained with coloration close to white, and comparative analyses were performed to verify the structural chemical composition, crystallinity, and morphology of the samples by techniques FTIR, DRX, and SEM, respectively. Then, once the biomaterial was purified, the range of applications expanded to several products to meet the biomedical area, sustainable packaging, and even the fashion industry.
\end{abstract}

Keywords: Bacterial cellulose; Kombucha; Purification; Crystallinity; Water; Alkali.

\section{Resumo}

A membrana de celulose bacteriana (BCM) é um biomaterial sintetizado por bactérias do gênero Gluconocetobacter hansenii com maior grau de pureza que a celulose vegetal. A matéria-prima comumente utilizada para a manipulação da celulose bacteriana é o kombuchá, bebida consumida por uma vasta população em todo o mundo que promete benefícios à saúde. A bebida é composta por chás da espécie Camellia sinenses e uma fonte de carbono, sacarose refinada, e uma cultura inicial de bactérias e leveduras com 10\% de chá fermentado (chá inicial) para ativar o processo fermentativo. As membranas de celulose bacteriana (KBCM) do Kombuchá são formadas ao longo de 7 a 10 dias na superfície do produto fermentado e têm a aparência de uma membrana gelatinosa, sendo este o subproduto de interesse. Neste trabalho, o objetivo foi produzir a membrana composta de celulose via Kombuchá e purificá-la para obter a celulose cristalina. A purificação foi realizada com água destilada e solução de hidróxido de sódio $\mathrm{NaOH} 0,5 \mathrm{M}$ para remoção dos resíduos da fermentação, com sucesso na remoção de açúcares e bactérias. Ao final dos experimentos, foi obtido um filme mais claro com coloração próxima ao branco, e análises comparativas foram realizadas para verificar a composição química estrutural, cristalinidade e morfologia das amostras pelas técnicas FTIR, DRX e SEM, 
respectivamente. Depois, uma vez purificado o biomaterial, o leque de aplicações se expandiu para diversos produtos para atender a área biomédica, embalagens sustentáveis e até mesmo a indústria da moda.

Palavras-chave: Celulose bacteriana; Kombuchá; Purificação; Cristalinidade; Água; Alcalino.

\section{Resumen}

La membrana de celulosa bacteriana (BCM) es un biomaterial sintetizado por bacterias del género Gluconocetobacter hansenii con un grado de pureza superior a la celulosa vegetal. La materia prima usada para manipular la celulosa bacteriana es la kombucha, una bebida consumida por una vasta población en todo el mundo que promete beneficios para la salud. La bebida se compone de la especie de té Camellia sinenses y una fuente de carbono, sacarosa refinada y un cultivo iniciador de bacterias y levadura con té fermentado al 10\% (té iniciador) para activar el proceso fermentativo. Las membranas de celulosa bacteriana de Kombucha (KBCM) se forman durante 7 a 10 días en la superficie del producto fermentado y tienen la apariencia de una membrana gelatinosa, siendo este el subproducto de interés. En este trabajo, el objetivo fue obtener la membrana compuesta de celulosa vía Kombucha y purificarla para obtener celulosa cristalina. La purificación se realizó con agua destilada y solución de hidróxido de sodio $\mathrm{NaOH} \mathrm{0,5} \mathrm{M} \mathrm{para} \mathrm{eliminar} \mathrm{los}$ residuos de la fermentación, eliminando con éxito azúcares y bacterias. Al finalizar los experimentos, se obtuvo una película más clara con coloración cercana al blanco, y se realizaron análisis comparativos para verificar la composición química estructural, cristalinidad y morfología de las muestras técnicas FTIR, DRX y SEM, respectivamente. Luego, una vez purificado el biomaterial, la gama de aplicaciones se expandió a varios productos para cubrir el área biomédica, el empaque sustentable e incluso la industria de la moda.

Palabras clave: Celulosa bacteriana; Kombucha; Purificación; Cristalinidad; Agua; Álcali.

\section{Introduction}

The interest in developing new biomaterials has expanded over time with analyses and studies in various industrial sectors because they have a shallow environmental impact. An example of a biopolymer to be used as a biomaterial is bacterial cellulose, whose format is purer than the cellulose provided by plants (Costa \& Biz, 2017).

Cellulose is a polysaccharide extracted from plant cells of plants such as eucalyptus, cotton, and trees (Wang et al., 2019). Besides non-woody plants such as hemp, jute, and sisal leaves (Alila et al., 2013). The problem for implementing the cellulose as a biotechnological material is the submission to drastic chemical treatments to remove lignin and hemicellulose, substances that are not of industrial interest. Moreover, a promising biotechnological material is a bacterial cellulose, which is in high demand for its unique properties, such as good crystallinity, high tensile strength, moldability, high degree of polymerization, and being a hundred times thinner than the cellulose fibers obtained from plants (Vandamme et al., 1998)

To be synthetically produced, it requires raw materials of high production cost (Vazquez et al., 2013). However, it was observed that BCM could be synthesized by good bacteria and come from some industrial residues such as sugarcane bagasse, soy molasses, coconut cream, fruits, and others(Dima et al., 2017).

There is a work that reports the effectiveness of obtaining bacterial cellulose by the bacterium Gluconacetobacter xylinus through rotten fruit; Jozala et al., (2015) reported in their study that it is essential to reduce waste and deploy these byproducts to extract another bioproduct of interest in this case BC, for different applications. Lin et al., 2014 demonstrated in their work that beer yeast residuals are a good nutrient source for Gluconacetobacter Hansenii for BC production, and the final properties and microstructures were as good as the conventional chemical method.

It is possible to obtain this biopolymer cheaply and easily through the ancient drink kombucha, consumed by many people worldwide (Aditiawati et al., 2021). This beverage consists of fermenting the tea of the Camellia Sinenses species along with an initial inoculum of bacteria, with the main bacteria being acetic: Acetobacter xylinum, A. xylinoides, A. aceti, A. pausterianus and Bacterium gluconicum and yeasts, such as Candida sp., Kloeckera sp., Schizosaccharomyces pombe, S. ludwigii, S. cerevisiae, Torulospora sp., Zygosaccharomyces bailii, and Pichia species along with refined sucrose used as a carbon source (Ugale, 2021). During fermentation of the liquid, a thick film forms on the surface of the beverage. This beverage, besides containing bacteria, yeast, and sucrose, contains cellulose (Goh, 2012). Therefore, it is of great interest to separate this material for study in biomedical applications, tissue engineering, orthopedics for bone regeneration, dental implants, vascular 
grafts, and adhesives to heal wounds, among others being studied for applications (Amarasekara et al., 2020). In addition to the biomedical area, the Kombucha's bacterial cellulose membranes (KBCM) can be applied in the textile industry, for the production of new sustainable leather-like fabrics (Domskiene et al., 2019) and in the biodegradable packaging industry (Tapias et al., 1947). However, purification of this kombucha membrane is required before any application to improve the biomaterial of interest.

Thus, in this work, the main goal was to submit the Kombucha's bacterial cellulose membranes (KBCM) to purification with an alkaline solution of $0.5 \mathrm{M}$ sodium hydroxide to remove the fermentative residues that are nucleic acids, sugars, and bacteria, leaving only the cellulose fibers in evidence, and increase the material crystallinity to extend the range of applications.

\section{Methodology}

\subsection{Obtaining Kombucha's bacterial cellulose membranes (KBCM)}

The methodology was based on the work of Jayabalan et al., (2014). For obtaining the bacterial cellulose membrane, it is necessary to prepare a sweet tea infusion with 1 liter of water together with $100 \mathrm{~g}$ of white sugar and 7 grams of black tea. The tea was left to infuse for 15 minutes. Then, the tea was cooled to room temperature and was placed in a glass container with a starter culture of bacteria and yeast with $100 \mathrm{ml}$ of already fermented tea to activate the fermentative process. The glass was covered with paper towels and held in place with a rubber band to avoid contamination for 10 days. Finally, a gelatinous film was obtained on the air-liquid surface and removed for further purification with distilled water and sodium hydroxide for comparison. The flow chart for obtaining the cellulosic membrane is shown in Figure 1.

Figure 1. Flowchart representative of obtaining the cellulosic membrane.

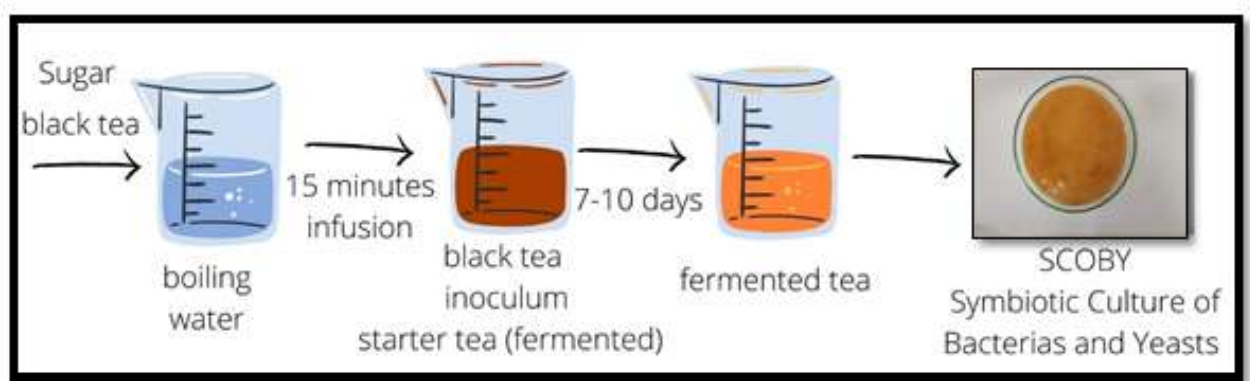

Source: Authors

\subsection{Purification of bacterial cellulose membranes from kombucha}

Two comparative purification methods were used in the purification step: the first with distilled water and the second with sodium hydroxide $\mathrm{NaOH}$. Both purifications used water bath equipment. These different ways of purifying the bacterial cellulose were used to compare results and to establish the most efficient method to obtain crystals.

\subsubsection{Purification of Kombucha's bacterial cellulose membranes (KBCM) with distilled water}

From purification stage, about $400 \mathrm{~mL}$ of distilled water was added to the KBCM and left in a water bath for 1 hour at $80^{\circ} \mathrm{C}$. The process was repeated four times until a white coloration was obtained. Subsequently, this membrane was separated and placed in a petri dish to dry in an oven at $50^{\circ} \mathrm{C}$ for 18 hours. 


\subsubsection{Purification of Kombucha's bacterial cellulose membranes (KBCM) with $\mathrm{NaOH}$}

The methodology of purification was based on the work of (Rangaswamy et al., 2015) and collaborators. An alkaline solution of $0.5 \mathrm{M} \mathrm{NaOH}$ was prepared for purification of the kombucha bacterial cellulose membrane. Around $75 \mathrm{~mL} \mathrm{of} \mathrm{NaOH}$ was added to a beaker with the KBCM. It was left in a water bath at $80^{\circ} \mathrm{C}$ for 15 minutes. Subsequently, to neutralize the $\mathrm{pH}$, $400 \mathrm{~mL}$ of distilled water was added to the $\mathrm{KBCM}$, again in a water bath at $80^{\circ} \mathrm{C}$ for one hour. This purification step was repeated four times until neutralization of the $\mathrm{pH}$. The steps are represented in Figure 2. Afterward, this membrane was separated and placed in a petri dish to dry in an oven at $50^{\circ} \mathrm{C}$ for 18 hours.

Figure 2. Alkaline purification steps.

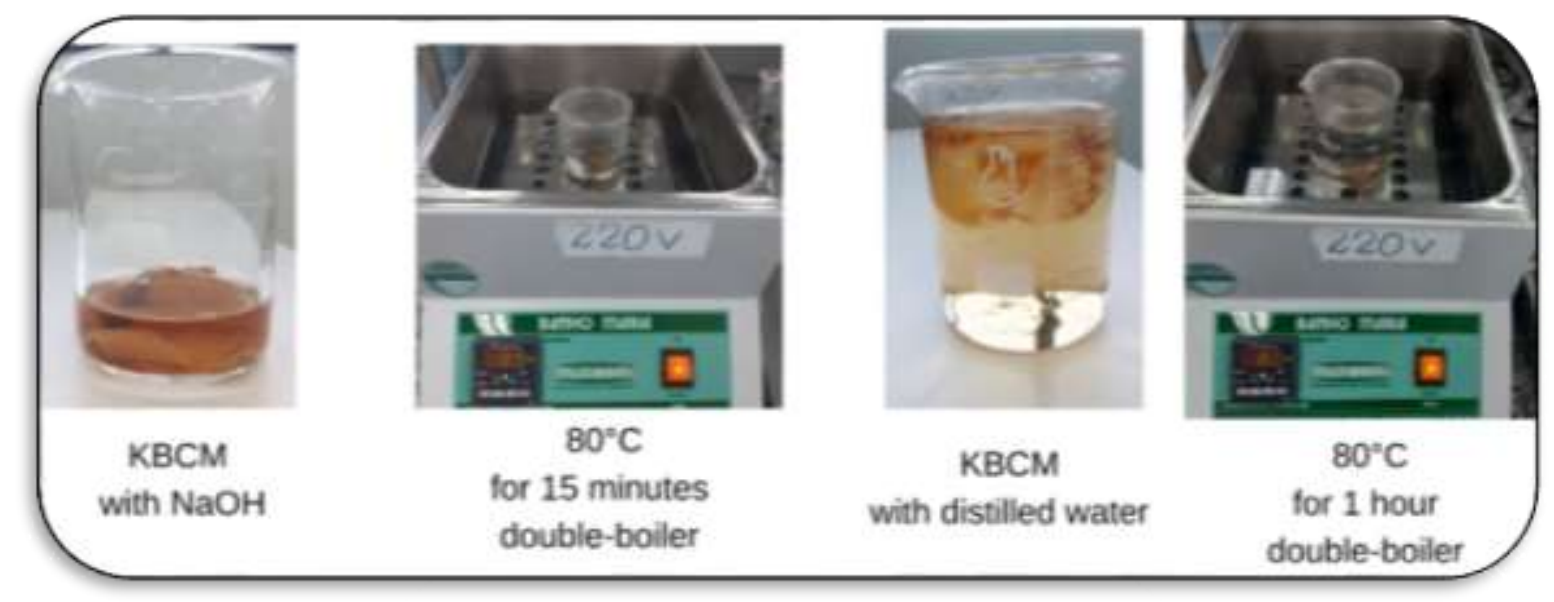

Source: Authors

\subsection{Characterization}

\subsubsection{Fourier Transform Infrared Absorption Spectroscopy (FTIR)}

The main functional groups present in the membranes were characterized via FTIR. It was also used for comparison of the chemical composition between the KBCM in natura and purified with distilled water and $\mathrm{NaOH}$. The characterization was performed in the Espectro 400 GX FT-IR equipment, in the Central Multiuser Laboratories in transmittance mode, with a range between 4000 and $500 \mathrm{~cm}^{-1}$.

\subsubsection{X-Ray Diffraction (XRD)}

To analyze the material's crystallinity, it was necessary to characterize by X-ray diffractometer (XRD). The analysis was performed in the film mode, with a divergence slit of $0.3 \mathrm{~mm}$, incidence angle theta $=1.5^{\circ}$, and angle 2 theta ranging between $10.0^{\circ}$ and $80.0^{\circ}$, with speed $2^{\circ} / \mathrm{min}$ and step of $0.02^{\circ}$. The X-ray beam generated by the copper target with a nickel filter allows only X-rays with wavelength $\lambda=1,5413 \AA$ to pass through with a wide range of applications in materials engineering. The XRD technique was also used to estimate the average crystallite size using the Scherrer equation (Maiti et al., 2013).

$$
D=k \lambda(\beta \cos \theta)^{-1} \quad \text { Equation } 1
$$

Where: $\mathrm{k}$ is an empirical proportionality constant, which varies with the geometric shape of the crystallite. To measure the peak width at half-height, $\mathrm{K}$ varies between 0.84 and 0.89 , depending on the geometry. If the geometry of the crystallite is 
not known, the spherical shape is adopted, and it is worth 0.90. $\lambda$ is the wavelength measured at the center of the peak obtained via $\mathrm{XRD}, \beta$ is the peak width measured at the average height, and $\theta$ is the Bragg reflection angle measured in radians.

\subsubsection{Scanning Electron Microscopy (SEM)}

To analyze the morphology of the KBCM, the dry sample was coated with a gold film via sputtering. The morphology of the fibers was analyzed via SEM and was performed in the Central Multiuser Laboratory (CLM in a Carl Zeiss EVO MA 10 Scanning Electron Microscope coupled with an integrated EDX system.

\section{Results and Discussion}

\subsection{KBCM Depigmentation}

Figure 3 contains four photographs of the KBCM depigmentation process in water and four photographs of the process with $\mathrm{NaOH}$. It can be comparatively observed in Figures 3(d) and 3(h) that there was discoloration in both the step with water and the step with $\mathrm{NaOH}$.

Figure 3. Depigmentation of the bacterial cellulose membrane

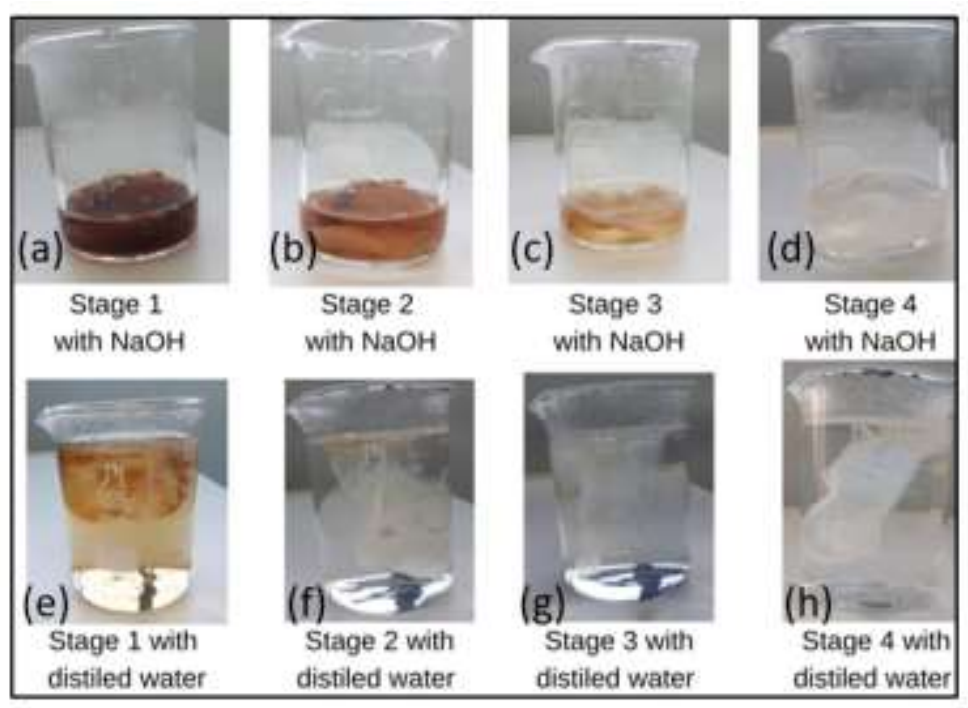

Sourse: Authors

It is possible to observe in Figures $4 \mathrm{~b}$ and $4 \mathrm{~d}$, the evolution of the depigmentation of the kombucha bacterial cellulose membrane; from a yellowish-brown coloration, it started to have a lighter coloration close to white; through this visualization, it is possible to observe the coloration variation between $\mathrm{KBCM}$ purified only with water and $\mathrm{KBCM}$ purified with $0.5 \mathrm{M} \mathrm{NaOH}$. The article by Laavanya et al., (2021)reports a relevance in the treatment through visual analysis. Moreover, they also visualized this depigmentation through the alkaline treatment in their research. 
Figure 4. a) KBCM before purification; b) KBCM after purification; c) KBCM before purification and dried; d) KBCM after purification and dried.

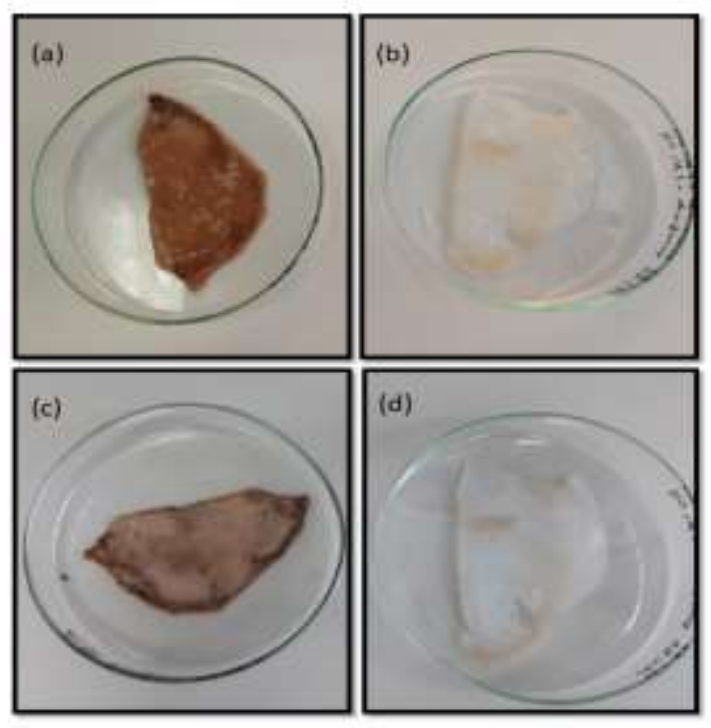

Source: Authors

\subsection{Fourier transform infrared spectroscopy (FTIR)}

The Fourier Transform Infrared Absorption Spectroscopy was aimed at presenting the molecular structure of which the cellulose membrane is composed in natura, blue line, purified with distilled water, red line, and purified with $\mathrm{NaOH}$, black line. We observe bands at 3259,3291, and $3342 \mathrm{~cm}^{-1}$ representing an intramolecular hydrogen stretching vibration, which are hydroxyl groups related to the water molecule. A decrease of these water groups on the membrane is noticed through these bands as the purification proceeds. The FTIR spectrum also shows at 2899, 2918, and $2886 \mathrm{~cm}^{-1}$ less pronounced absorption bands, which indicates the stretching of $\mathrm{C}-\mathrm{H}$ bonds, and a much smaller peak of these compounds can be seen when the membrane was purified with $\mathrm{NaOH}$. In the bands 1652 and $1633 \mathrm{~cm}^{-1}$, it shows absorption of the $\mathrm{C}=\mathrm{O}$ group. The bands at 1145,1151 , and $1106 \mathrm{~cm}^{-1}$, indicate the presence of the NH group. According to Li et al., (2019) and collaborators the peaks representing proteins are 1062.6$1059.1 \mathrm{~cm}^{-1}$; however, in this work, these peaks for the membrane proteins were 926, 1010, and $1016 \mathrm{~cm}^{-1}$. The results of the spectra of pure KBCM, KBCM purified with water, and KBCM purified with $\mathrm{NaOH}$ are shown in Figure 5. The amide and protein groups were reduced, probably due to the temperature and $\mathrm{pH}$ action of the $\mathrm{NaOH}$ treatment. 


\section{Figure 5. FTIR spectra of KBCM}

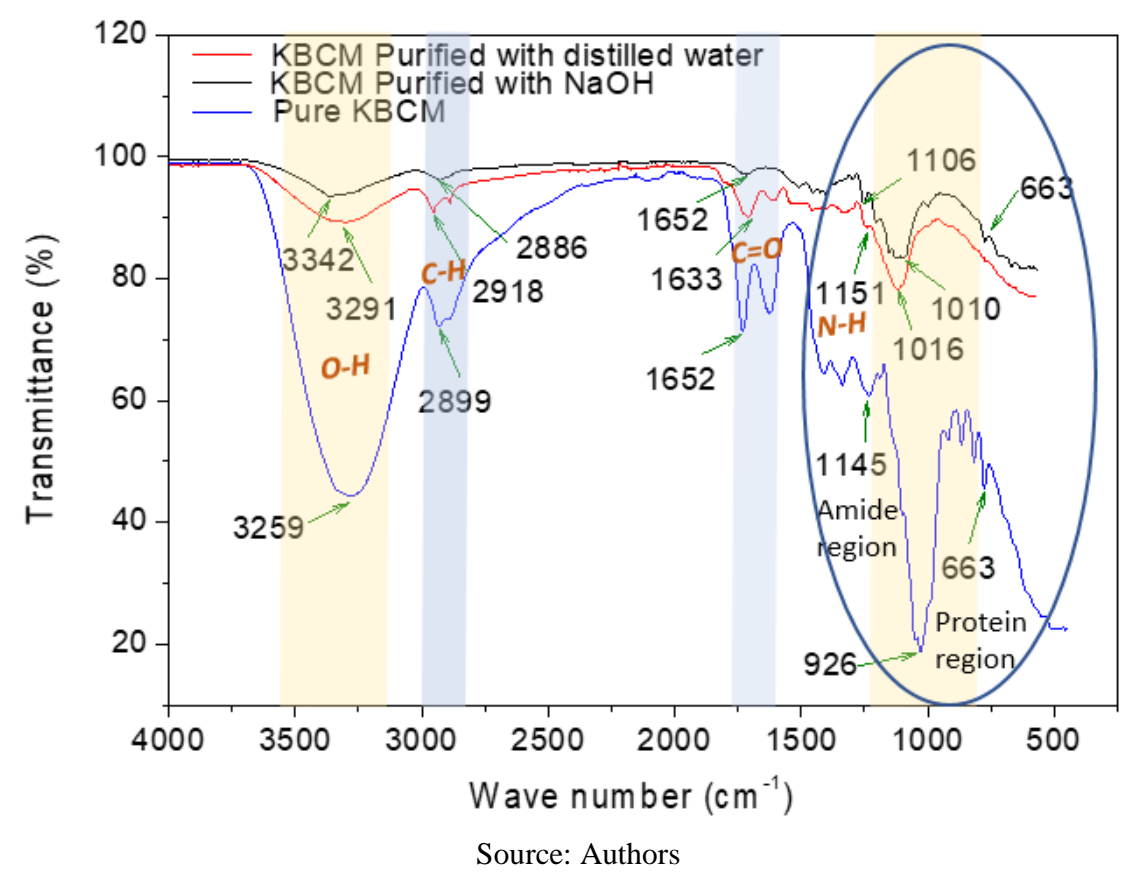

\subsection{X-Ray Diffraction (XRD)}

Crystallized cellulose is found in four polymorphic phases, but two are widely studied: type I - cellulose (native) and type II - cellulose (regenerated). Native cellulose is the most common and can be divided into I $\alpha$ and I $\beta$. KBCM has typical characteristics of type I $\alpha$ cellulose, as observed in the diffractogram of Figure 6, the prominent peaks at 14.5, 16.6, and 22.6, typical values of type I crystalline cellulose with structures (- $\left.\begin{array}{lll}-1 & 0 & 1\end{array}\right),\left(\begin{array}{lll}1 & 0 & 1\end{array}\right)$, and ( $\left.\begin{array}{lll}0 & 0 & 2\end{array}\right)$, according to previous studies by Karina et al., (2012). There was an increase in the peaks when the membrane was subjected to alkaline treatment compared to the low peaks of pure KBCM; therefore, the membrane showed an increase in crystallinity. The $\mathrm{X}$-ray diffractometers of Pure and $\mathrm{NaOH}$ purified KBCM are shown in Figure 6. 
Figure 6. Diffractometer from KBCM.

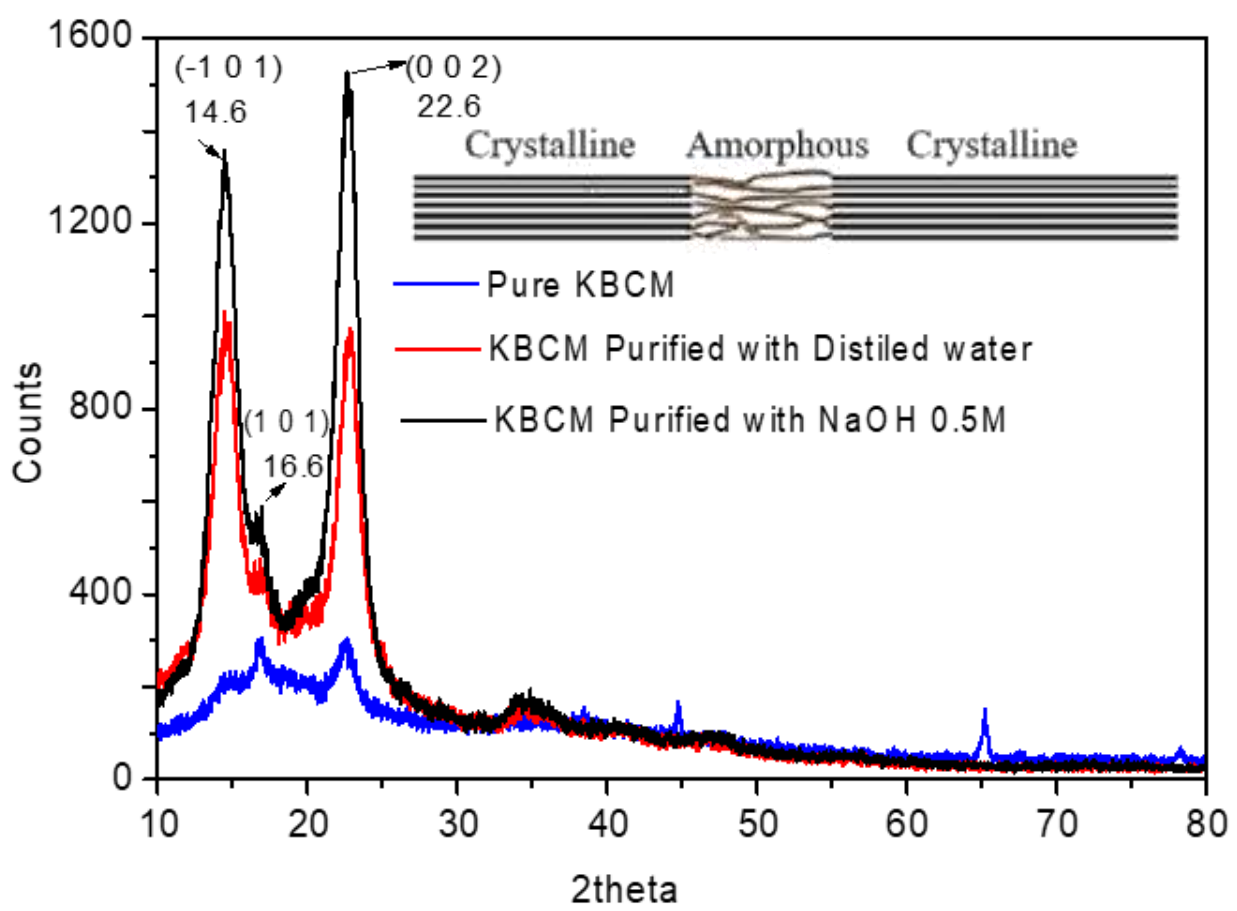

Source: Authors.

Table 1 contains the data and the estimated average crystallite size for the pure KBCM samples, purified with distilled water + heating and purified with 0.5 molar $\mathrm{NaOH}$ solution + heating. Note that the crystalline planes that intensified the most after the purification process were $\left(\begin{array}{lll}0 & 0 & 2\end{array}\right)$ and $\left(\begin{array}{lll}1 & 0 & 1\end{array}\right)$, with the $\left(\begin{array}{lll}0 & 0 & 2\end{array}\right)$ plane showing the most remarkable change in diameter, indicating greater efficiency in the purification process with $\mathrm{NaOH}$.

Table 1. Data and estimated average crystallite size for pure and purified KBCM samples with water and $\mathrm{NaOH}$

\begin{tabular}{|c|c|c|c|c|c|c|c|c|c|}
\hline Samples & K & $\lambda(\mathrm{nm})$ & $\mathrm{k} \lambda(\mathrm{nm})$ & $\beta(F W H M)^{*}$ & $\theta$ & $\cos \theta$ & $(\beta \cos \theta)-1$ & $\begin{array}{c}\mathrm{D}=\mathrm{k} \lambda(\beta \cos \theta)-1 \\
(\mathrm{~nm})\end{array}$ & $\begin{array}{l}\text { Crystalline } \\
\text { planes }\end{array}$ \\
\hline \multirow{2}{*}{$\mathrm{KBCM}-\mathrm{H}_{2} \mathrm{O}$} & 0.90 & 15.41 & 13.87 & 3.20 & 14.60 & 0.97 & 0.32 & 4,48 & $\left(\begin{array}{lll}-1 & 0 & 1\end{array}\right)$ \\
\hline & 0.90 & 15.41 & 13.87 & 2.70 & 22.70 & 0.92 & 0.40 & 5.57 & $(002)$ \\
\hline \multirow[b]{2}{*}{$\mathrm{KBCM}-\mathrm{NaOH}$} & 0.90 & 15.41 & 13.87 & 2.58 & 14.61 & 0.97 & 0.40 & 5.56 & $\left(\begin{array}{lll}-1 & 0 & 1\end{array}\right)$ \\
\hline & 0.90 & 15.41 & 13.87 & 2.04 & 22.63 & 0.92 & 0.53 & 7.37 & $(002)$ \\
\hline \multirow[b]{2}{*}{ KBCM-pura } & 0.90 & 15.41 & 13.87 & 5.06 & 16.06 & 0.96 & 0.21 & 2.87 & $\left(\begin{array}{lll}1 & 0 & 1\end{array}\right)$ \\
\hline & 0.90 & 15.41 & 13.87 & 2.18 & 22.51 & 0.92 & 0.50 & 6.89 & $(002)$ \\
\hline
\end{tabular}

* Full width at half maximum of the peak (FWHM). Source: Authors.

\subsection{Scanning Electron Microscopy}

The morphology of the cellulosic membrane was analyzed by the SEM technique and is represented in Figure 7. One can observe in Figure 7(a) the morphology of KBCM in natura, (b) Morphology of KBCM purified with water (c), and Morphology of KBCM purified with $\mathrm{NaOH}$ (d). The presence of bacteria of the genus Gluconacetobacter hansenii, which produces the cellulose fibrils, can be observed. After alkaline purification, no more bacteria could be seen, as they were removed from the membrane. In Figures $7 \mathrm{c}$ and $7 \mathrm{~d}$, only a tangle of fibrils randomly disordered with respect to directions was noticed. It 
was reported in the work of Souza and Recouvreux, (2016) the randomness of cellulosic fibrils produced by the bacterium Gluconacetobacter hansenii.

Figure 7. KBCM morphology a) and b) Morphology of KBCM purified with water c) and d) Morphology of KBCM purified with $\mathrm{NaOH}$.
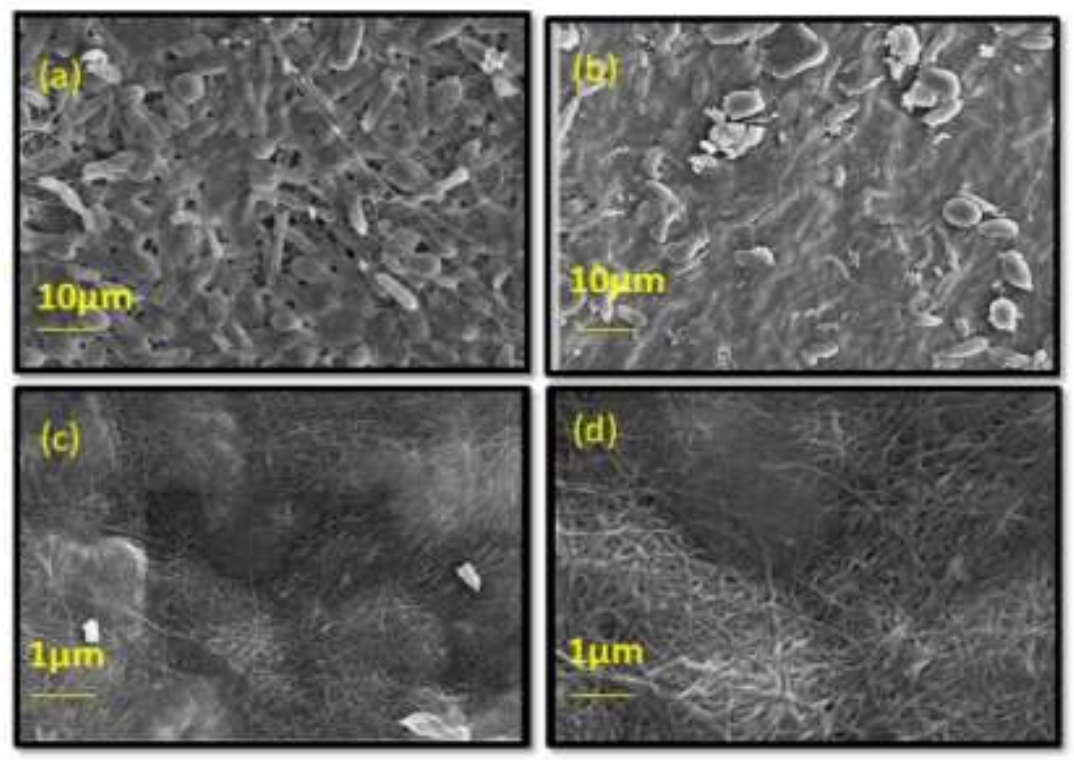

Source: Authors.

\section{Conclusion}

It was possible to obtain bacterial cellulose membrane by fermenting the millennial beverage kombucha, made from sweetened tea with sucrose and a symbiotic culture of bacteria and yeast. This membrane was separated for treatment with distilled water and weak alkaline treatment of $0.5 \mathrm{M}$, where it was possible to dry these membranes and characterize them by FTIR, XRD, and SEM techniques to analyze the molecular composition, crystallinity, and morphology of the fibrils. The results obtained were satisfactory, decreasing the water band of the biomaterial, increasing the crystallinity, and removing impurities in the membrane, such as bacteria. With the purification performed, it will be possible to further study the material for use as a product, such as in biomedicine and tissue engineering, as a biomaterial reinforcement.

\section{References}

Aditiawati, P., Dungani, R., Muharam, S., Sulaeman, A., Hartati, S., Dewi, M., \& Rosamah, E. (2021). The Nanocellulose Fibers from Symbiotic Culture of Bacteria and Yeast (SCOBY) Kombucha: Preparation and Characterization. In Nanofibers - Synthesis, Properties and Applications. IntechOpen. https://doi.org/10.5772/intechopen.96310

Alila, S., Besbes, I., Vilar, M. R., Mutjé, P., \& Boufi, S. (2013). Non-woody plants as raw materials for production of microfibrillated cellulose (MFC): A comparative study. Industrial Crops and Products, 41(1), 250-259. https://doi.org/10.1016/j.indcrop.2012.04.028

Amarasekara, A. S., Wang, D., \& Grady, T. L. (2020). A comparison of kombucha SCOBY bacterial cellulose purification methods. SN Applied Sciences, 2(2). https://doi.org/10.1007/s42452-020-1982-2

Costa, P. Z. R. D. C., \& Biz, P. (2017). Cultivando materiais: o uso da celulose bacteriana no design de produtos Growning materials: the use of bacterial cellulose in product design.

Dima, S. O., Panaitescu, D. M., Orban, C., Ghiurea, M., Doncea, S. M., Fierascu, R. C., Nistor, C. L., Alexandrescu, E., Nicolae, C. A., Trica, B., Moraru, A., \& Oancea, F. (2017). Bacterial nanocellulose from side-streams of kombucha beverages production: Preparation and physical-chemical properties. Polymers, 9(8). https://doi.org/10.3390/polym9080374 
Domskiene, J., Sederaviciute, F., \& Simonaityte, J. (2019). Kombucha bacterial cellulose for sustainable fashion. International Journal of Clothing Science and Technology, 31(5), 644-652. https://doi.org/10.1108/IJCST-02-2019-0010

Goh, W. N. (2012). Fermentation of black tea broth (Kombucha): I. Effects of sucrose concentration and fermentation time on the yield of microbial cellulose. In International Food Research Journal 19 (1).

Jayabalan, R., Malbaša, R. v., Lončar, E. S., Vitas, J. S., \& Sathishkumar, M. (2014). A review on kombucha tea-microbiology, composition, fermentation, beneficial effects, toxicity, and tea fungus. In Comprehensive Reviews in Food Science and Food Safety 13(4), 538-550. https://doi.org/10.1111/1541-4337.12073

Jozala, A. F., Pértile, R. A. N., dos Santos, C. A., de Carvalho Santos-Ebinuma, V., Seckler, M. M., Gama, F. M., \& Pessoa, A. (2015). Bacterial cellulose production by Gluconacetobacter xylinus by employing alternative culture media. Applied Microbiology and Biotechnology, 99(3), 1181-1190. https://doi.org/10.1007/s00253-014-6232-3

Karina, M., Indrarti, L., Yudianti, R., Indriyati, \& Syampurwadi, A. (2012). Alteration of Bacterial Cellulose Properties by Diacetylglycerol. Procedia Chemistry, 4, 268-274. https://doi.org/10.1016/j.proche.2012.06.037

Laavanya, D., Shirkole, S., \& Balasubramanian, P. (2021). Current challenges, applications and future perspectives of SCOBY cellulose of Kombucha fermentation. In Journal of Cleaner Production (295). https://doi.org/10.1016/j.jclepro.2021.126454

Li, J., Chen, G., Zhang, R., Wu, H., Zeng, W., \& Liang, Z. (2019). Production of high crystallinity type-I cellulose from Komagataeibacter hansenii JR-02 isolated from Kombucha tea. Biotechnology and Applied Biochemistry, 66(1), 108-118. https://doi.org/10.1002/bab.1703

Lin, D., Lopez-Sanchez, P., Li, R., \& Li, Z. (2014). Production of bacterial cellulose by Gluconacetobacter hansenii CGMCC 3917 using only waste beer yeast as nutrient source. Bioresource Technology, 151, 113-119. https://doi.org/10.1016/j.biortech.2013.10.052

Maiti, S., Jayaramudu, J., Das, K., Reddy, S. M., Sadiku, R., Ray, S. S., \& Liu, D. (2013). Preparation and characterization of nano-cellulose with new shape from different precursor. Carbohydrate Polymers, 98(1), 562-567. https://doi.org/10.1016/j.carbpol.2013.06.029

Rangaswamy, B. E., Vanitha, K. P., \& Hungund, B. S. (2015). Microbial Cellulose Production from Bacteria Isolated from Rotten Fruit. International Journal of Polymer Science, 2015. https://doi.org/10.1155/2015/280784

Souza, L., \& Recouvreux, D. O. S. (2016). NANOCRISTAIS DE CELULOSE BACTERIANA A PARTIR DE HIDRÓLISE ENZIMÁTICA Bacterial Cellulose Nanocrystals from Enzymatic Hydrolysis.

Tapias, Y. A. R., Peltzer, M. A., Delgado, J. F., \& Salvay, A. G. (1947). Kombucha Tea By-product as Source of Novel Materials: Formulation and Characterization of Films. https://doi.org/10.1007/s11947-020-02471-4/Published

Ugale, V. (2021). Preparation of kombucha tea review on:Different kinds of microorganism's used for development of the kombucha. International Journal of Advances in Engineering and Management (IJAEM), 3, 815. https://doi.org/10.35629/5252-0302815822

Vandamme, E. J., de Baets, S., Vanbaelen, " A, Joris, K., \& de Wulf', P. (1998). Improved production of bacterial cellulose and its application potential. Polymer Degrnddon and Sfabihfy 59.

Vazquez, A., Foresti, M. L., Cerrutti, P., \& Galvagno, M. (2013). Bacterial Cellulose from Simple and Low Cost Production Media by Gluconacetobacter xylinus. Journal of Polymers and the Environment, 21(2), 545-554. https://doi.org/10.1007/s10924-012-0541-3

Wang, J., Tavakoli, J., \& Tang, Y. (2019). Bacterial cellulose production, properties and applications with different culture methods - A review. Carbohydrate Polymers 219, 63-76. https://doi.org/10.1016/j.carbpol.2019.05.008 